\title{
Batas Ekologi untuk Pembangunan Berkelanjutan Menggunakan Metode UETs di Wilayah Utara Propinsi Mie, Jepang
}

\section{Ecological Limit for Sustainable Development on the Northern Region of Mie Prefecture, Japan Using UETs Method}

\author{
ANUGERAH WIDIYANTO ${ }^{1 *}$, ERWINA WIDJAJAWATI ${ }^{2}$ \\ ${ }^{1 *}$ Balai Inkubator Teknologi, Badan Pengkajian dan Penerapan Teknologi \\ ${ }^{2}$ Pusat Teknologi Kawasan Spesifik dan Sistem Inovasi, Badan Pengkajian dan Penerapan Teknologi \\ Gedung 720, Puspiptek Serpong, Tangerang Selatan 15314 \\ Email: anugerah widiyanto@yahoo.com
}

\begin{abstract}
ABSTRAK
Perencanaan penggunaan lahan yang berkelanjutan memerlukan analisis mendalam tentang sumber daya alam yang ada (localizer, features, kepekaan terhadap pembangunan) dan pemahaman tentang karakteristik pembangunan (kebutuhan sumber daya dan side effecs) untuk mengidentifikasi penggunaan sumber daya alam pada kriteria keberlanjutan yang artinya bahwa pembangunan dapat didukung secara ekologis. Dalam konteks ini, beberapa metode menggunakan konsep ambang batas (thresholds concept) untuk menetapkan batas kemampuan lingkungan untuk mendukung pengembangan pembangunan yang direncanakan sumber daya alam yang tidak akan merugikan kehidupan generasi masa depan. Salah satu metode ini adalah UETs (Ultimate Environmental Thresholds) yang dikembangkan dan diterapkan dengan tujuan mengidentifikasi ambang batas akhir kemampuan lingkungan untuk pembangunan. Integrasi UETs dan GIS dikembangkan dalam penelitian ini untuk mengidentifikasi ambang batas lingkungan untuk pengembangan daerah pemukiman di Wilayah Utara Propinsi Mie, Jepang. Hasil dari penelitian ini adalah penilaian ambang batas toleransi hutan terhadap pembangunan pemukiman perkotaan.
\end{abstract}

Kata kunci: pembangunan berkelanjutan, nilai ekologi, ambang batas, UETs dan GIS

\begin{abstract}
Sustainable land use planning is essential to determine the most efficient use of existing natural resources that will not prejudice future development. There is a need to analyze relationships between natural resources and development to assess development possibilities which are based ecologically. Some methods use thresholds concept to establish the limits environment ability to support planned development. One of these methods is the Ultimate Environmental Thresholds (UETs) which develop and apply with the aim of identifying the environmental thresholds for development. The integration UETs method and GIS was developed as a means of identifying of this study areas and development level to which various forms of residential areas should be confined on the Northern Region of Mie Prefecture, Japan. The outcome of this study that is the territorial thresholds of forest tolerance to urban development have established.
\end{abstract}

Keywords: sustainable development, ecological value, thresholds, UET and GIS 


\section{INTRODUCTION}

\subsection{Background}

The ecosystem concept forms the fundamental basis in the ecological approach to land use planning. The ecosystems is an open systems composed of interrelated non-living and living elements. The ability of ecosystems to adjust to impacts of development activities must be analyzed, assessed and evaluated against the limits within the ecosystems conditions.

The concept of limits is well implicated in the field ecological studies. The described system option is to overcome energy issues and environmental limitation while also maintains sustainable development ${ }^{(1)}$. Some of the ecological assumption underlying the environmental limits approaches the sustainable development of agriculture. They also developed modeling carrying capacity for national parks ${ }^{(2,3)}$. This capacity ultimately limited by environmental thresholds to accommodate development impacts and requirements ${ }^{(4)}$.

To the strategy for sustainable living, sustainable development is commonly seen as ".....improving the quality of human life while living within carrying capacity of supporting ecosystems...."(5). The concept links directly with that of final limit of the earth's ecosystems to the impact they can withstand without irreversible damage.

Sustainable development strongly implies that recognition of final development limits, derived from the requirements of the natural environment, is the main step to be urgently taken. It is the same in planning; there will be no use in dealing with the problem in a more detail and sophisticated way before these limits are identified in the early stage of any planning.

The aims of the research is to develop model by adaptation of the thresholds method and to examine the model develop to analyze the environmental thresholds Northern Region of Mie, Japan, as the study area. In this study, environmental threshold method has been designed to indicate final ecological limits for sustainable development.

In this study, it was decided that with some modification, Ultimate Environmental Thresholds (UETs) and Geographical Information Systems (GIS) were to be used collaboratively to provide a comprehensive approach. UETs method is a land use planning technique for the definition of territorial, quantitative, qualitative and temporal UETs and provide an ecologically sound base, called solution space for the formulation of development strategies or policies with regard to their location, scale, type and timing ${ }^{(6)}$. Geographical Information Systems (GIS) is a power tool for monitoring and modeling for urban development ${ }^{(7,8,9,10)}$. GIS overlay techniques are used to assign environmental features such as wetlands, slope, fault zones, floodplains, as well as policy constrains such as urban growth boundaries, to individual land parcels $^{(11,12)}$. This comprehensive method were be used to identify areas and development level to which various forms of residential areas should be confined on the Northern Region of Mie Prefecture, Japan. Spatial analysis of the interrelationship between natural resources and development is necessary if decisions about the location of the development are to be based on ecological criteria(13,14,15). The spatial domain which will define territories from which particular activities ideally should be excluded on environmental grounds ${ }^{(16,17)}$. As a result, three types of environmental tolerance thresholds zone to which various forms of residential development are investigated and established.

\subsection{Objective}

The analysis of the research indicate these thresholds considered as the final boundary to possible location of development, or the final limit of what natural environment can take without irreversible damage. The result being the planning contribution towards defining carrying capacity which indicate what preferred and dominant function should be promote and where is ecologically safe would become especially relevant.

\section{MATERIAL AND METHODOLOGY}

\subsection{The Northern Region of Mie Prefecture, Japan}

The Northern region of Mie has been identified as one of the major developing areas of Mie Prefecture for both immigrating populations and its increasing urban facilities and activities. This is largely attributed to its location between Nagoya and Yokkaichi.

The primary feature of the Northern Region of Mie is its abundance of natural landscape. The northern part (over $400 \mathrm{~m}$ above sea level) is the most mountainous and is dominated by forest stands, with slopes that exceed $20 \%$. There is some farming in the lower part of this layer $(100-400 \mathrm{~m})$ and extended forest clearing can also be found in this part. The remaining 
landform types in the southern part is almost totally cleared for residential and other urban facilities that has resulted into major changes to the existing forest and agriculture.

The second dominant feature is urban development, which is largely concentrated in the south of Northern region of Mie. This emphasizes the obvious overspill, which is occurring from two cities of Nagoya and Yokkaichi. It can also be indicated that human intervention affected the southern part first and then its effect extended to the northern part of this region.

The continuation of this trend for urban development, however, is neither guaranteed nor permanent. Sustainable development of urban facilities/ activities in a sensitive environment requires that ecological limits of the environment be not exceeded.

\subsection{Methodology}

The environmental limitations of the urban development are established using UETs and GIS method. The UET method is to assist in determining environmentally safe land use possibilities of the area concerned on the basis of the analytical process which would ensure that environmental elements of highest value and/or of degree of resistance and transformation be identified and accordingly safeguard $(6,18,19)$. This study deals in some detail with those aspects of the UET method which concern flora as the main elements in any natural environment. This study also concentrates mainly up on territorial thresholds; however, some consideration of the qualitative dimension of thresholds approach was also undertaken.

The integrating of current UETs method and GIS offer an important opportunity for developing an integrated sustainable development-modeling framework in the urban area. Geographic Information Systems (GIS) have emerged as useful computer-based tools for spatial description and manipulation. The extension of UET method integrates with GIS appears to be viable and necessary.

The aspect of UET are amenable to extension without compromising its basic thrust (1) Geographic Information Systems (GIS) to facilitate development, overlay and quantification of maps. (2) Numerical scales for individual elements to allow quantification (3) formal procedures for combining groups of UET elements into single classification or map (20). Indeed, these outlined that GIS (1) provides methods for deriving maps from sample surveys and analysis data on map systems (2) combined information from different topics and (3) provides useful tools for suitable and sound decisionmaking ${ }^{(21)}$. Using the results of the UETs analysis it was then possible to overlay management policies through development of guiding statements as parts of the GIS analysis $^{(11,20,22,23)}$.
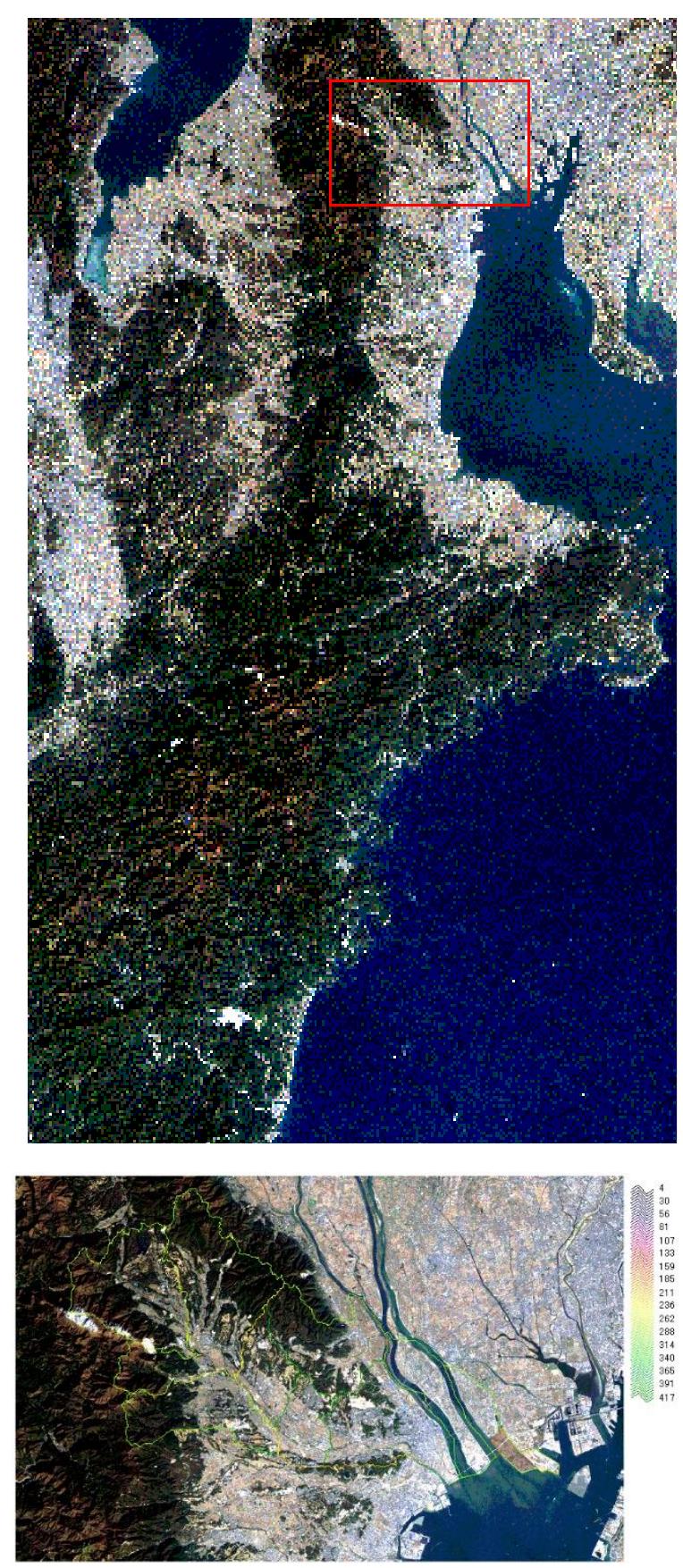

Figure 1. Scope of this study area

The study area was examined using the Idrisi 32 GIS software. The data available for this study include topography, land use classification, soil map, forest maps. 
Topographic attributes, slope, elevation and aspect layers were calculated from Digital Elevation Model (DEM) data with resolution of $50-\mathrm{m}$. Using the commonly of the surface analysis module of Idrisi 32, three layers are derived from DEM data, namely elevation data, slope gradient and slope aspect. The soil map used in this research is based on soil map of Mie prefecture. The map covering the study area describes the soil unit and reclassified into seven unit of soil: Brown Forest soil, dry brown forest soil, andosols, Yellow soil, gray low land soil, grey soil and immature regosols soil. General characteristics of soil profile was described and classified according to the FAO systems (see Figure 1).

The collaborative methods fulfils the prime objective of environmentally based planning by assessing the development possibilities of environments through identification of stress limit beyond which development must be excluded if development is to be sustainable $24,25,26)$.

In order to establish the value of investigated forest, the area of Northern region of Mie divided into number of forest districts (rinpan). Two hundred two rinpan were distinguished and characterized on the basis analysis and assessment of particular forest elements within them. Classified Land use/land cover, DEM data, Forest Function and Plan Map were useful data sources and providing an excellent platform for this analysis ${ }^{27,28,29)}$.

The analysis and assessment were carried out using criteria which include uniqueness, resistance and transformation. Appropriate classes distinguished within each criterion were applied. The result of the analysis and assessment for each rinpan then were recorded in separate data files using GIS. Synthesis of all resources categories into a total study area analysis to be performed to establish territorial environmental thresholds (the zone so environmentally sensitive that all transgression has to be excluded).

\section{RESULT AND DISCUSSION}

\subsection{Establishing the value of forest}

Thresholds can be determined by combining the potential threats and assessment of the main environmental elements. The assessment is expressed by degree of ecological value of the resources involved. In this stage, firstly the value of forest is established and development activities (present and future) defined. Secondly, the interactions in the ecosystems and between forests are examined in relation to their value (using ecological value criteria) and activities. This stage is mainly complete by creating databases and is enhanced by using GIS. Scores from the three ecological values were aggregated into a single matrix to identify the low, medium and the greatest degree. Ecological value criteria include uniqueness, Transformations and resistance finally, these scores from all three categories were aggregated into single matrix and were summed to form to identify environmental territorial thresholds.

The Uniqueness criterion, in principle, has been adopted from the UET method and it is understood as a spatial differentiation of occurrence of a given resources or its elements. For the purpose of establishing forest tolerance, uniqueness can be determined by scarcity or abundance of given forest ${ }^{(30,31,32,33)}$. The uniqueness of a given environmental element is indicated as any element or resources has a unique value providing the ecosystems itself, or a component part, and is ecologically important or already subjugated to some form of protection. Specific protection is required for elements that have highest value and safeguard the distinct environmental character and ecologically important of a given local area. Survival of the elements is particularly threatened if degree of occurrence and their size of population are low. For this reasons it is recommended that assessment of uniqueness be carried out by identifying the degree of occurrence in the area concerned. These qualitative classes of forest can be distinguished in this stream: unique, rare and common.

Transformation determined the degree of modification or the condition of forest in relation to its original state. To assess the degree of transformation known areas of natural vegetation cover were compared with area currently occupied by vegetation known to be either introduced or succession. Changes of species composition and changes in plant communities and removal of the plant cover were recognized as a major transformation from natural state. Land use categories and vegetation map for a given area provide an excellent platform for the analysis ${ }^{(9)}$. Any historic records and information would also be of significant assistance in the case of vegetation and fundamental in the case of analyzing forest transformations. In the context of Northern region of Mie Prefecture, transformation 
determined the degree of modification of the condition of forest in relation to its original state. Changes in plant communities and removal of the plant cover recognized as a major transformation from natural state. The analysis should aim not only at objective environmental evaluation but also at the identification of acceptable limits for transformation. It is suggested that three major classes which described the degree of transformations can be distinguished: low; partial and high.

Resistance is defined as the ability of the ecosystem to maintain relationships within it and to respond to disturbance. In the context of the Northern region of Mie forest region the following factors determining resistance of forest were identified. Slopes altitude above sea level, type of tree and biological attributes of plants forming a given community. To assess resistance have recommended map of plant communities and DEM data. To examine the physical parameter contributing to the initiation of resilience, the resilience of forest were correlated with those parameter considered to have influence on their resilience ${ }^{(34)}$. In the context of the Northern region of Mie Prefecture, the following factors determining resilience of forest were identified. These physical parameter include slope, elevation, aspect and soil.

Figure 2 shows an example for the basic data of topographic attributes, slope, elevation and aspect layers were calculated from Digital Elevation Model data.

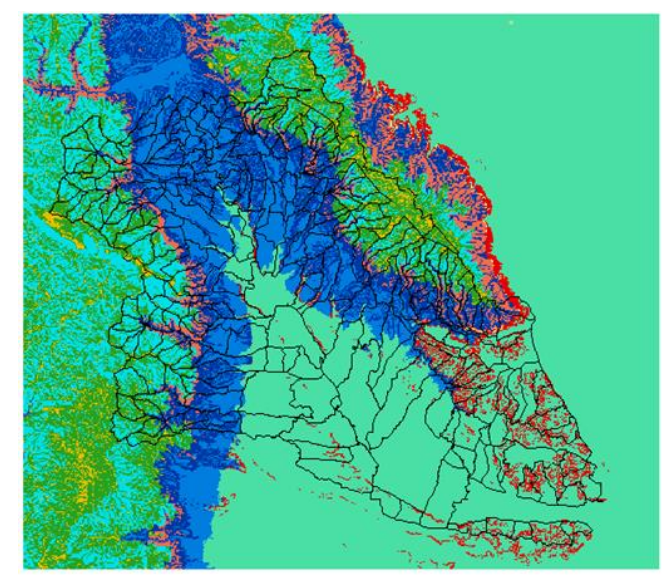

$0-150 \mathrm{~m} \mid 0-10$ degrees

$150-400 \mathrm{~m}$ | $0-10$ degrees

$400 \mathrm{~m}$ and greater $\mid 0-10$ degrees

$0-150 \mathrm{~m} \mid 11-29$ degrees

$150-400 \mathrm{~m} \mid 11-29$ degrees

$400 \mathrm{~m}$ and greater $\mid 11-29$ degrees

$0-150 \mathrm{~m} / 30$ degrees and greater

$150-400 \mathrm{~m} / 30$ degrees and greater

$400 \mathrm{~m}$ and greater $\mid 30$ degrees and greater

Figure 2. Cross-Classification between Slope and elevations
In the original UET schema, uniqueness, resistance and transformation elements each have fixed sets of non-numerical values and binary overlays produce integrated UET maps. Areas which are unique and/or have nil resistance are exclusion zones whereas areas which are common and have high resistance may be development zones. If three elements are expressed as numerical values, quantification and finer resolution analyzes are possible. GIS's algebraic capabilities allow UET to expand from its current binary rules for combining maps to the use of numerical scales on individual maps and algorithm for combining maps $^{(21)}$. Finally, the integrated UET maps will be classified by ranges of overall UET value and the areas measures by UET range. As a result the following classes of uniqueness, transformation, resistance of forest were distinguished (see Figure 3).
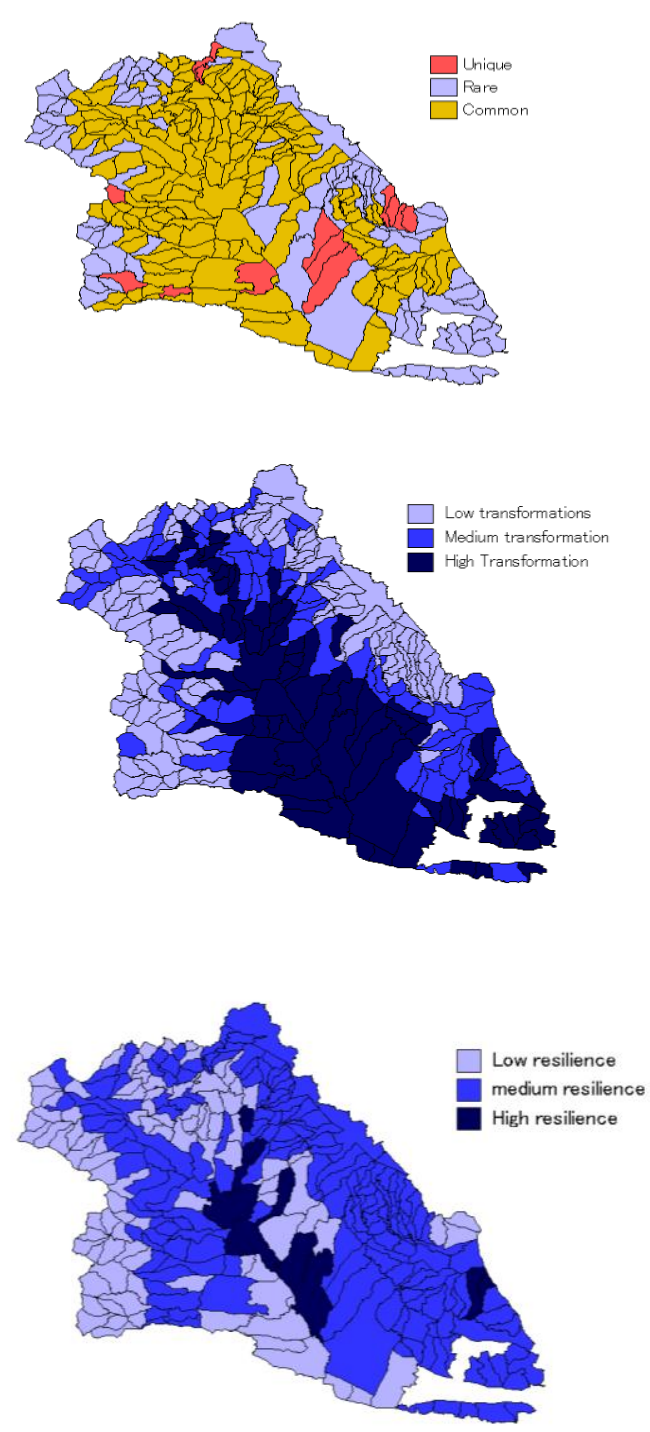

Figure 3. Ecological value of Forest 


\subsection{Determination of "Territorial" Environmental Thresholds and Establish Zone of Forest Tolerance}

Establishment territorial thresholds zone through determining ecological value. The option concentrates mainly upon territorial thresholds; however some consideration of the qualitative dimension of thresholds approach was also undertaken. The principal objective was to isolate the zone exclusion. Territorial Thresholds was defined through selection of criteria pertaining to uniqueness, resilience and transformation. It was indicated that zones for total exclusion were considered to be areas in which any of the environmental elements considered to be unique or any of the environmental elements considered to be rare or common with low/minor resilience and with only minimal and partial transformation. Following this, qualitative dimension were derived by determination of two further zone within solution space (tread lightly zone and heavier demand zone). The identification of these zones permitted the allocation of activities to areas of appropriate environmental tolerance.

This part of the process consists of determining the boundaries of the territory in which some area can be permitted and some others excluded for residential development. In this phase partial territorial environmental thresholds were determined first. Criteria or decision rules for the definition of territorial UETs were established. The criteria emerged from the examination from the examination of uniqueness and transformation of forest, by identification of their resistance to the residential development. Steps towards the determination of territorial environmental thresholds were performed using Idrisi 32. Data files, in which information on uniqueness, resistance and transformation was recorded, were used to identify areas where most limitation for a given residential development existed. These results provided the basis set criteria for defining respective UETs in relation to the residential development. The criteria indicated, in particular, what combination of uniqueness, transformation; resistance should determine a UET in each case. Twenty-seven maps of zones were determined through a combination of degree of uniqueness, transformation and resistance.

As a result of the synthesis of these combinations, three types of zone of forest tolerance defined. As the principal objective was to isolate and establish the zone of exclusion,
Figure 4 shows the territorial thresholds/total exclusion zone for residential development (the zone so environmentally sensitive that all transgression has to be excluded). As a result it can calculate that the area percentage of different land use types was estimated that 66.74 per cent belongs to strict reserves (total exclusion area) and 33.26 per cent to solution space. With more land available within the solution space, the location of middle to the northern part would provide an urban area for the increasing population. Therefore, uncontrolled new development of urban area in this area leads to the conflict land use and maximum loss of soil in the region future. In summary, an overall adaptation of Environmental Thresholds approach provides a simple approach that can be useful tool in defining city's carrying capacity.

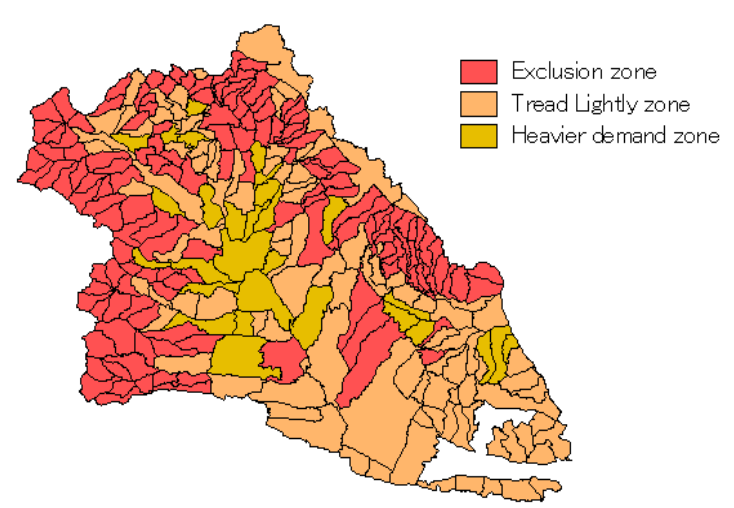

Figure 4. Territorial environmental thresholds zone

\section{CONCLUDING REMARKS}

Provision of urban facilities alone is not sufficient. Planning with an understanding of the value and effectiveness of the location of these facilities and their effect on the environment is the crucial element in success. The most critical underlying factor is that the entire residential development rests on a base of natural resources. These affinitive resources are the foundation for the growth of residential development to spoil or utilize these resources without care a long-term outlook will result in their destruction and ultimate loss.

The application of various thresholds in the planning process, and in particular Environmental Thresholds, ensures that erosion of resources, upon which residential development is based, is minimized, and that those resources which have a unique and/or ecological value are protected. This balanced 
approach of both restrictive and promotional planning will ensure that the available resources are rationally and responsibly allocated and managed for sustainable urban development.

In summary, an overall assessment of the application of the thresholds approach (using UETs and GIS) in the Northern region of Mie and as a potential technique for other urban development, could be best for fundamental and important opportunity for developing a framework of integrated model for sustainable urban development and its links to the environment.

\section{REFERENCES}

1. Watanabe, C. (1999). System option for sustainable development-effect and limit of the Ministry of International Trade and Industry's efforts to substitute technology for energy, Research Policy, 28(7), 719-749.

2. Tait, J., \& Morris, D. (2000). Sustainable development of agricultural Systems: competing objectives and critical limits, Futures, 32(3-4), 247-260.

3. Prato, T. (2001). Modeling carrying capacity for national park. Ecological Economics. 9(3), 321-331.

4. Sanga, N. K., \& Widjajawati, E. (2004). Environmental Limitation: A framework for sustainable development on the Northern Region of Mie using UETs and GIS, GIS $A$ conference, Tokyo, Japan Vol.13, pp 121-124.

5. IUCN, UNEP, \& WWF. (1991). Caring for the earth- A strategy for sustainable living, Gland.

6. Kozlowski, J. (1986). Thresholds Approach in Urban, Regional and Environmental Planning, University of Queensland Press, St.Lucia, London, New York.

7. Kozlowski, J., Rosier, J., \& Hill, G. (1988). Ultimate Environmental Thresholds (UET) method in a marine environment (Great Barrier Reef Marine Park in Australia), Landscape and Urban Planning, 15(3-4), 327336.

8. Kozlowski, J. (1990). Sustainable development in professional planning: a potential contribution of the EIA and UET concepts, Landscape and Urban Planning, 19(4), 307-332.

9. Sanga, N. K. (2003). Quantitative estimation of $\mathrm{CO} 2$ sequestration by forest systems in Mie using GIS and RS, Proc. MU GIS Society. Vol3. 2003.

10.Sanga, N. K., Lizuka, K., \& Kobayashi, S. (2012). Estimating CO2 Sequestration by Forests in Oita Prefecture, Japan, by Combining LANDSAT ETM+ and ALOS Satellite Remote Sensing Data. Remote Sensing. 4(11), 3544-3570.

11. Waddel, P., \& Alberti, M. (1998) Integration of An Urban Simulation Model and Urban Ecosystems Model, Proc International environment and GIS vol2/1998, Hongkong.

12.Shattri, M., Nordin, A., \& Rashid, S. GIS Based Multicriteria Approaches to Housing Site Suitability Assessment. Shaping the Change. XXIII FIG Congress. Munich, Germany, October 8-13, 2006.

13. Setiawan, N. N., Vanhellemont, M., Baeten, L., Van de Peer, T., Ampoorter, E., Ponette, Q., \& Verheyen, K. (2015). Local neighbourhood effects on sapling growth in a young experimental forest, Forest Ecology and Management, 384, 424-443.

14. Kapfer, J., Hedl, R., Juransinski, G., Kopecky, M., Schei, F. H., \& Grytnes, J. A. (2017). Resurveying historical vegetation data opportunities and challenges. Applied Vegetation Science, 20(2), 164-171.

15. Arya, M., Geetha, P., \& Soman, K. P. (2017). Effect of Wind Farms in Crop Production of Kanyakumari District. Indian Journal of Science and Technology, 8(28), 641-645.

16. Chamagne, J., Tanadini, M., Frank, D., Matula, R., Paine, T., Philipson, C.D., Philipson, Svatek, M., Turnbull, L. A., Volaric, D., \& Hector, A. (2016). Forest diversity promotes individual tree growth in central European forest stands. Jounal of Applied Ecology, 54 (1). 71-79.

17. Baeten, L., Hermy, M., \& Verheyen, K. (2009). Environmental Limitation Contributes to the Differential Colonization Capacity of Two Forest Herbs. Journal of Vegetation Science. 20(2). 209-223.

18. Breuste, J. H. (2004). Decision making, planning and design for the conservation of indigenous vegetation within urban development, Landscape and Urban Planning 68(4), 439-542.

19. Brandon, T., \& Bestelmeyer, (2006) Threshold Concepts and Their Use in Rangeland 
Management and Restoration: The Good, the $\mathrm{Bad}$, and the Insidious, Restoration Ecology 14(3), 325-329.

20.Burrough, P. A. (1986). Principles of Geographic Information Systems for Land resources assessment, Monograph on soil and resources survey vol 12, Oxford University Press.

21. Sanga, N. K. (2000). GIS and Remote Sensing for sustainable man-nature coexistence, MU GIS Society. Vol1. 2000.

22. Klosterman, R. E. (1995). The appropriateness of geographic information systems for regional planning in the developing world. Computers, Environment and Urban Systems, 19(1), 1-13.

23. Baeten, L., Verheyen, K., \& Collins, B. (2017). Changes in the nature of environmental limitation in two forest herbs during two decades of forest succession, Vegetation Science, 28(5). 883-892.

24. Van de Peer, T., Verheyen, K., Baeten, L., Ponette, Q., \& Muys, B. (2016). Biodiversity as insurance for sapling survival in experimental tree plantations, Journal of Applied Ecology, 53(6), 1777-1786.

25. Van Den Berge, S., Beaten, L., Vanhellemont, M., Ampoorter, E., Proesmans, W., Eeraerts, M., Hermy, M., Smagghe, G., Vermeulen, I., \& Verheyen, K. (2018). Species diversity, pollinator resources value and edibility potential woody networks in the countryside in norther Belgium, Agriculture, Ecosystems \& Environment, 259(1), 119-126.

26. Ratcliffe, S., Wirth, C., Jucker, T., \& Beaten, L. (2017). Biodiversity and ecosystem fuction relations in European forest depend on environmental context, Ecology Letters, 20(11). 1414-1426.

27. Kobayashi, S., Omura, Y., Sanga, N. K., Yamaguchi, Y., Widyorini, R., Fujita, M. S., Supriadi, B., \& Kawai, S. (2015). Yearly Variation of Acacia Plantation Forests Obtained by Polarimetric Analysis of ALOS
PALSAR Data, IEEE Journal of selected topics in applied earth observations and remote sensing, 8(11). $5294-5304$.

28. Shiraishi, T., Motohka, T., Thapa, R. B., Watanabe, M., \& Shimada, M. (2014). Comparative assessment of supervised classifiers for land use-Land cover classification in a tropical region using timeseries PALSAR mosaic data, IEEE J. Sel. Topics Appl. Earth Observations and Remote Sensing, 7(4), 1186-1199.

29. Singh, G., Yamaguchi, Y., \& Park, S. E. (2013). General four-component scattering power decomposition with unitary transformation of coherency matrix, IEEE Transaction Geosicence and Remote Sensing, 51(5). 3014-3022.

30.Mori, S. A., Lertzman, K. P., Gustafsson, L. (2017). Biodiversity and ecosystem services in forest ecosystems: a research agenda for applied forest ecology, 54(1), 12-27.

31.Baeten, L., Jacquemyn, H., Calster, H. V., Beek, E. V., Devlaeminck, R., Verheyen, K., \& Hermy, M. (2009). Low recruitment across life stages partly accounts for the slow colonization of forest herbs.journal of ecology, 97(1), 109-117.

32. Verheyen, K., Baeten, L., Frenne, D. G., Roemerann, M. B., Brunet, J., Cornelis, J., Decocq, G., Dierschke, H., Eriksson, O., \& Hedl, R. (2012). Driving factors behind the eutrophication signal in understorey plant communities of deciduous temperate forests. Journal of Ecology. 100(2). 352-365.

33. Groote, S. D., Lantman, I. M. V. S., \& Sercu, B.K. (2017). Tree species identity outweighs the effects of tree species diversity and forest fragmentation on understorey diversity and composition. Plant Ecology and Evolution. 150(3).229-239.

34. Arrowsmith, C., \& Inbakaran, R. (2002). Estimating environmental resilience for the Grampians National Park, Victoria, Australia: a quantitative approach, Tourism Management, 23(3), 295-309 